\title{
Lawmakers and Lobbyists: Policy Outreach through One-Minutes and Press Releases
}

\author{
Christine DeGregorio
}

Elites in Washington behave as if the successful passage of controversial policy rests on their ability to reach the American people with a clear and resonant argument. With an aim toward understanding the strategic nature of this discourse, I examine the themes most repeated by allies and adversaries in five, high profile policy battles of the 107th Congress (2001-2002). The data include one-minute speeches offered by lawmakers on the House floor (274) and press releases (495) posted on the Web pages of the involved interest-groups. The results provide evidence on the determinants of polarized, policy discourse and affirm that no one party, nor interest group-type, dominates policy promotion.

Campaigns for votes over policy resemble campaigns for votes over elective office. Both contests entail rhetorical appeals by elites to the masses. In fact, for members of the House with biennial elections, the two campaigns are almost indistinguishable. In this setting, more than in the Senate, lawmakers are beholden to attentive citizens throughout their service. To maintain a modicum of decision making leeway in Washington, House members negotiate their relationships with voters in frequent visits home and attentive outreach from the nation's capital (Fenno 2000). To forge agreements over policy in this increasingly polarized chamber (Sinclair 2006), coalition builders make strategic use of personal favors (Evans 2004), restrictive rules (Sinclair 2007; Smith 2007) and language (Evans 2001; Krehbiel 1995; Niven 1996). Moreover, the most committed policymakers find allies in the interest group community who have the members and means to lend support for their causes (Chin et al. 2000; Cobb and Elder 1983; DeGregorio 1997; Hall and Deardorff 2006).

With these conditions in mind, I inquire into the promotional speech that legislators and lobbyists adopt to pursue their interests in policy. Do allies, recognizing the value of simplicity and repetition in their outreach, find common symbols and phrases to justify support? And to the extent that allies accomplish a united rhetorical front, do adversaries from the compet-

I want to acknowledge R. Sam Garrett, currently with the Congressional Research Service, and anonymous reviewers for their valuable insights and encouragement.

CHRISTINE DEGREGORIO is an associate professor of government at American University.

The American Review of Politics, Vol. 31, Summer, 2010: 113-135

(C)2010 The American Review of Politics 


\section{4 | Christine DeGregorio}

ing sides inevitably talk past each other, producing confusing and irreconcilable interpretations of events.

I leave for another day the macro effects of strategic framing and focus here on the conditions that affect the contours of policy discourse in the public sphere. Mayhew (1974, 2000), Riker (1996) and others (Abramowitz 2001; Hurley 2001) make sound positive as well as normative arguments for pursuing this line of inquiry. First, there are positive insights to be learned from taking account of the observable, rhetorical choices that interest-seeking elites make in constrained environments. The results add credence to, among other things, the importance of personal ambition, historical experience and institutional setting. Second, there are normative implications to studying the content and quality of policy discourse. Citizens pay attention to these public actions and judge their policy champions accordingly. In this regard, the results provide evidence on the determinants of polarized discourse and affirm that no one party, nor interest group-type, dominates policy promotion.

The evidence entails two types of outreach: 274 floor speeches (lawmakers) and 495 press releases (lobbyists). The arguments have as their focus any one of five initiatives of the 107th Congress: No Child Left Behind Act (H.R. 1), Securing America's Future Energy (SAFE) Act (H.R. 4), Economic Growth and Tax Relief Reconciliation Act (H.R. 3 and subsequently H.R. 1836), Agricultural Security Act (H.R. 2646), and Airport Security Act (S. 1447). The full design follows a summary of scholarly insights that can be applied to promotional campaigns over public policy.

\section{Theoretical Roots}

Elites, legislators and lobbyists alike frame issues to advance their interests. ${ }^{1}$ Sometimes quite subtle alterations in language can eliminate from consideration unwanted alternatives. I give three examples. Bill Zeliff (R-NH) discouraged opposition to a budget bill by first manipulating its title to sound inclusive and benign. After finding a cosponsor from a short list of Democrats whose surnames started with A, his newly named "A to Z Spending Plan," went on to accumulate broad bipartisan support, just as Zeliff intended (Krehbiel 1995). Campaign finance reform provides a more highprofile case. Here the opposing sides lined up with two dominant themes: block the bill to protect free speech or pass the bill to protect officials from the corrupting influence of money. According to Dwyre and Farrar-Myers (2000), it was the free-speech frame that stalled passage of McCain-Feingold in the early years. In a more remote case, Krebbs and Jackson (2007) connect the Palestinians' victory in securing the franchise in Israel to their skill in blocking opposition by making a 'no' vote too unpalatable for ordinary 
citizens to cast. In each instance, the elites framed the debate to remove from serious consideration the popular alternative they wanted to defeat. As such, they all fit nicely with Shanto Iyengar's view of framing $(1994,11)$ when he writes, "At the most general level, the concept of framing refers to subtle alterations in the statement or judgment and choice problems."

Prudent users of political speech subscribe to Frank Luntz's (2006) admonition that it is not what you say but what audiences hear that counts. With effectiveness in mind, scholars tell us that audiences learn best when they are presented with a simple, homogeneous picture of events (Zaller 1992; Iyengar 1994). The coherence discourages the 'misinformation' that occurs when people 'fill-in' the blanks to fit their own, possibly misguided, view of the facts (Hofstetter et al. 1999; Chong et al. 1983; Goffman 1974). Moreover, negative themes purportedly capture attention better than positive themes (Kahneman and Tversky 1979; Hansen 1985; Truman 1951; Riker 1996). However admirable policy allies may deem these tenets of effective speech, I anticipate next several circumstances that likely undermine their attainment. From congressional scholarship, these pertain to individuals' perspectives, their institutional settings, and broader conditions that surround each issue.

Take legislators first. They are notoriously resistant to partisan coordination because they are beholden to different sets of voters at election time (Mayhew 1974). ${ }^{2}$ And between elections they adjust their words and actions, even in Washington, to fit highly personalized expectations from home (Fenno 2000; Lipinski 2004). To confront the communications challenge, both parties have in place a mechanism - a speakers' bureau of sorts - that is chaired by an elected official and staffed with communications experts to help willing members hone and coordinate their messages (Morris 2001; Rocca 2007). Nothing compels participants to adhere to the prepared language, but the members' willingness to devote limited time to this effort bodes well for message coordination within parties. That the most talkative members often come from the ideological extremes of their respective parties further suggests that differences in message making will abound between the parties (Maltzman and Sigelman 1996).

Owing to history, the Republicans' Theme Team is more formalized than the Democrats' Message Group. ${ }^{3}$ In the late 1980s and early 1990s Republican leaders of the so-called "permanent minority" found it difficult to spread their message through traditional media outlets (Connelly and Pitney 1994; Cook 1998; Gingrich 1997). They compensated for the disadvantage by debating amongst themselves. In a barrage of one-minute speeches, some railing against the Democrats and some envisioning a better future, Republicans addressed the nation, unfiltered, via cable television (CSPAN). Several observers credit the Republicans' 1994 victory to this clever 
use of micro media (Berry 1999; Roberts and Roberts 1995). Not to be outdone, the new Democratic minority was soon to follow suit, when their Chief Whip David Bonior (D-MI) redefined his job to include message coordination from the floor during the one-minute venue (Kahn 1995).

While scholars concur that the leaders of both parties value message coordination through one minutes (Berry 1999; Aldrich and Rohde 1997; Harris 1998), questions remain as to differences in their management styles. Guided by past successes, Republicans may rely on this venue more than Democrats. Alternatively, Democrats may engage in more speech-making, owing to their minority status at the time of this study (Maltzman and Sigelman 1996).

Just as House members face competing demands from their constituents, party leaders, and colleagues (Kingdon 1973; Fenno 2000), advocacy groups face competing demands from their member volunteers. With the long-term stability of their organizations in mind, group leaders do what they can to avoid behavior that undermines order and harmony within their ranks (Ainsworth 2000). The logic helps to explain why groups make different tactical choices when it comes to campaign involvement and public outreach. ${ }^{4}$ Thus we encounter another plausible source of disunity, even among groups that would otherwise find it sensible to speak with one voice.

The asymmetries that emerge between wielding positive and negative power also likely affect the number, homogeneity and tone of the adversaries' massage frames (Riker 1996; Jerit 2008). Policy promoters, be they legislators or lobbyists, face the burdensome task of assembling votes to pass policy in ever widening and unpredictable arenas (Sinclair 2007). The task is daunting, considering that one rhetorical misstep can unravel the emerging coalition. ${ }^{5}$ The communications challenge for opposition forces is mild by comparison. There are many opportunities to block passage, and the reasons to do so need not be coordinated around a unified theme. ${ }^{6}$

Policies also create their own micro-climates that affect the strategic use of rhetoric (Baumgartner 2007; Page 1996). Depending on the subject matter, some issues are easier to convey in ideological terms than others. Given their track records, moreover, the parties establish reputations for certain policy terrains and accompanying message frames (Egan 2008; Luntz 2006; Lipinski 2004). And subject matter aside, policy debates occur within larger political contexts that have consequences for rhetoricians. The upheaval in the aftermath of the 2000 presidential race may inspire different themes, for example, than the period of heightened patriotism in the wake of September 11, 2001. Depending on the audience, framers may appeal in one instance to shared fears and at another instance to cultural values (Sigelman et al. 2001).

In sum, disagreements over public policy resemble campaign-style politics with success more and more contingent on who has the most resonant 
argument. Lawmakers and lobbyists know it is in their interest to work together, mobilizing constituents who will prod wavering representatives into casting the 'right' vote. Yet message-makers who share the same interests in passing or blocking legislation have a variety of reasons 'not' to sound coherent when they talk about policy. Different institutional incentives and rules introduce conditions that likely undermine the supply of common rhetorical themes. Where stressing the negative may help lobbyists draw new members and energize their base, stressing the positive may help lawmakers take credit for sponsoring good public policy. It may be rational, as well, for campaigners in policy disputes to adopt different outreach strategies. Whereas proponents of a policy may feel the need to coordinate around a few central themes, opponents may not. And if one side feels disadvantaged in traditional media outlets, this side (typically the House minority) should make more frequent use of reaching C-SPAN audiences through oneminute speeches.

\section{The Design}

Anticipating that policy contexts draw out different advocates and arguments, I examine the speech that emerged around five initiatives of the 107th Congress. Taking the frame analysis one issue at a time, we see the quality and content of promotional outreach within a single environment; participants make the most of a shared situation. The five-case comparison lets us observe for rhetorical variations that elites make under different circumstances.

Legislators and lobbyists have many avenues at their disposal for addressing the nation on policy. I examine interest group press releases and House members' one-minute speeches because both offer an undistorted look at how the two sets of players characterize, in their own words, the policies before them. While different—one written and the other oral- they have in common three characteristics that make them especially amenable for comparison. First, they are brief. The participants, regardless of format, typically limit themselves to 300 words. Second, both venues are relatively barrier-free. Participation is thus voluntary and accessible. Maintaining Web addresses to educate and mobilize internet users is a ubiquitous tactic among advocacy groups; even resource poor organizations post press releases. Similarly, 'unconstrained' floor time is available nearly every morning for all members, regardless of status (majority or minority), seniority, or committee expertise. The parties alternate the time, giving neither side an advantage. Third, communications experts in both settings advise their participants on message content. Finding examples of coordinated speech in Congress is admittedly difficult; House members are famously individualistic and entre- 
preneurial. That said, with the encouragement of C-SPAN to amplify their message, House leaders are becoming quite adept at using unconstrained floor time each morning to coordinate their parties' positions on policy (Evans 2001; Harris 2005). If we are to capture signs of coordinationwithin parties and among allies - this is a good place to look.

The 274 speeches, offered by 165 House members, were identified through subject-matter searches of the Congressional Record available through Lexis-Nexis. The search protocol included the phrase ' 1 minute' along with a bill specific reference (e.g., 'child left behind,' 'comprehensive energy,' 'tax relief,' 'airport security,' and the like). The 495 press releases, posted by 75 interest groups, resulted from a Lexis-Nexis search of five major newspapers: The New York Times, The Washington Post, Washington Times, Chicago Sun Times, Houston Chronicle, and Los Angeles Times. The search protocol included the words 'lobby' and 'Congress' along with the subject matter of the policies (education, energy, tax cuts, farm, and airport security). ${ }^{7}$ The search period spans the 107 th Congress (2001-2002).

I use a team approach to 'frame' identification in order to minimize idiosyncratic interpretations of the intended language. Only when the principal investigator and research assistant concur on the common-sense meaning of a repeated theme do we give it a label (frame) and include it for coding. The documents were searched electronically for these and additional frames, made suitable owing to their repetition. ${ }^{8}$

Two frames recur with sufficient regularity to make comparisons across policy domains. These are (1) speech about process (e.g., hearing, markup and vote) and (2) speech about the future (e.g., goals, aims, mission). Subject-matter differences across bills also necessitate several issue-specific frames (e.g., 'class size' for education, 'big oil' for energy, 'people's money' for tax reform, etc.). For an illustration of the coding in a typical document see the Appendix.

Last, the selected bills vary in ways that are useful for this analysis. For example, they reach different sized audiences (scope) and remain on the congressional agenda for varying lengths of time. Evidence on these and other aspects of the legislation come from the Library of Congress's website (http://thomas.loc.gov).

\section{The Findings}

\section{Setting the Stage: Promotional Activity in Context}

Two conditions likely affect the public attention bills receive: their intended scope and the duration of time they remain unsettled on the national agenda. A numerical measure of the policies' scope comes from the 
lists of indexing terms that the Library of Congress uses to categorize all bills. The issues under consideration, here, involve middling to high scope. The broadest - farm security (558) and energy security (444) — entail a complex maze of provisions that reach national and international audiences. The narrowest gauge policy is Aviation Security, which contemplated federalizing airport security, a national focus affecting a narrow sector within our economy.

The bill's duration is measured in months and spans the period from bill introduction to bill signing. The four policies that were enacted within the study period vary in duration from less than a month (tax reform) to nine months (education reform). The debate over energy policy continued through the summer of 2005. All but two initiatives were subject to numerous amending activities in the House, my focus here. The exceptions are tax reform and aviation security. Three of five votes on passage in the House were bipartisan and sizable. The two partisan votes occurred over energy and taxes.

Table 1 provides a snapshot of promotional activity, while accounting for scope, duration and the like. The breakdown suggests several insights. First, supporting messages outnumber blocking messages in four out of five campaigns. While we might have expected opponents to make more public appeals on behalf of threatened communities, such is not the case. Rather, we see more outreach from the bills' champions, befitting the narrative that it takes more work to pass policy than to block it. Second, lobbyists' press releases outnumber legislators' one-minute floor speeches, sometimes by large margins. This result conforms to the dominant view that lobbyists provide legislators much-needed support: money, information and outreach. Presumably, the more lobbyists champion the lawmakers' interests, the less the lawmakers need do the outreach themselves. ${ }^{9}$ And third, the evidence does little to support the idea that promotional outreach corresponds strongly with the initiative's anticipated scope or time allotted for negotiation. While attention to energy overhaul is intense and fits these criteria, tax reform receives ample attention and is resolved in less than a month. Indeed, what distinguishes the three issues that attract the most attention is another circumstance entirely - their prominence in the presidential campaign rhetoric of George W. Bush. We next examine the content of the messages within and across policies.

\section{Message Framing: Discord to Harmony}

Table 2 divides the frames into three categories of speech along the five policies. The center column lists the frames that are common to supporters and opponents alike. These are best described as incidents of conversation, 
Table 1. Promotional Activity, Bills, and Reception in the U.S. House

\begin{tabular}{|c|c|c|c|c|c|c|c|c|c|}
\hline \multicolumn{4}{|c|}{-Promotional Activity- } & \multirow{2}{*}{ Bill } & \multirow[b]{2}{*}{ Short Title } & & \multirow[b]{2}{*}{ Votes $^{\mathrm{a}}$} \\
\hline Pro & Con & $\begin{array}{c}\text { Press } \\
\text { Releases }\end{array}$ & $\begin{array}{c}\text { One- } \\
\text { Minutes }\end{array}$ & & & Scope & $\begin{array}{l}\text { in } \\
\text { Months }\end{array}$ & $\begin{array}{l}\text { Amend- } \\
\text { ments }\end{array}$ & \\
\hline 32 & 71 & 78 & 25 & H.R. 1 & $\begin{array}{l}\text { No Child } \\
\text { Left Behind }\end{array}$ & 300 & 9 & 27 & $\begin{array}{l}384-45 \\
381-41\end{array}$ \\
\hline 197 & 142 & 241 & 98 & H.R. 4 & $\begin{array}{l}\text { Energy } \\
\text { Security }\end{array}$ & 444 & $\mathrm{na}^{\mathrm{b}}$ & 16 & $\begin{array}{l}240-189 \\
\text { na }\end{array}$ \\
\hline 100 & 66 & 73 & 93 & H.R. 1836 & $\begin{array}{l}\text { Economic } \\
\text { Growth and } \\
\text { Tax Relief } \\
\text { Reconciliation }\end{array}$ & 228 & 1 & 1 & $\begin{array}{l}230-197 \\
240-154\end{array}$ \\
\hline 62 & 29 & 83 & 8 & H.R. 2646 & $\begin{array}{l}\text { Farm } \\
\text { Security }\end{array}$ & 558 & 10 & 42 & $\begin{array}{l}291-120 \\
280-141\end{array}$ \\
\hline 45 & 25 & 20 & 50 & S. 1447 & $\begin{array}{l}\text { Aviation } \\
\text { Security }\end{array}$ & 165 & 2 & 0 & $\begin{array}{l}\text { Voice } \\
410-9\end{array}$ \\
\hline
\end{tabular}

Notes: ${ }^{\mathrm{a}}$ The first vote in each cell is the vote on initial floor passage. The second vote is the vote on the conference bill. ${ }^{\mathrm{b}}$ The debate over energy continued until 2005.

with adversaries in the conflict engaging the legislation in the same terms. To the left are the frames that the bills' opponents emphasize, and to the right are the frames that supporters emphasize. In each case, these determinations are based on difference of means tests with probabilities of $\leq .05$ ). Scanning vertically from one policy to the next, we see a gradual shift from heterogeneous frames in education documents to more homogeneous frames in farm documents.

This distribution of frames provides an excellent window into the nature of these debates. For Democrats and their allies, the way to solve the problem with public-school education is to improve student-teacher ratios ('class size') and infuse more federal money ('funding'). The Republicans and their allies never mention 'class size' or 'funding.' Rather, they champion 'flexibility' as a means to fix deficiencies in public schools. Both sides of this debate acknowledge the need to improve our schools ('performance'). Both sides kept their audiences informed on what was going on in Congress ('process').

The adversaries in this debate provide a good example of heterogeneous communication. Democrat George Miller (CA-7) uses 'class size' to 


\section{Table 2. Frame Usage by Policy, Commonalities and Disparities by Institutional Positions, House (votes listed parenthetically)}

\begin{tabular}{|c|c|c|c|}
\hline Policies (House Vote) & $\begin{array}{l}\text { Frames Used } \\
\text { by Opponents }\end{array}$ & $\begin{array}{l}\text { Frames Shared } \\
\text { by Both Sides }\end{array}$ & $\begin{array}{l}\text { Frames Used } \\
\text { by Supporters }\end{array}$ \\
\hline $\begin{array}{l}\text { Education (bipartisan } \\
\text { supermajority) }\end{array}$ & $\begin{array}{l}\text { Funding } \\
\text { Problem } \\
\text { Class Size }\end{array}$ & $\begin{array}{l}\text { Process } \\
\text { Performance }\end{array}$ & $\begin{array}{l}\text { Flexibility } \\
\text { Future }\end{array}$ \\
\hline Energy (partisan) & $\begin{array}{l}\text { Problem }(\mathrm{O}>\mathrm{L}) \\
\text { Big Oil } \\
\text { Efficiency }(\mathrm{L}>\mathrm{O})\end{array}$ & $\begin{array}{l}\text { Conservation } \\
\text { Dependency } \\
\text { Future }\end{array}$ & $\begin{array}{l}\text { Process }(\mathrm{L}>\mathrm{O}) \\
\text { Economy } \\
\text { Expansion }\end{array}$ \\
\hline Tax (partisan) & $\begin{array}{l}\text { Priorities }(\mathrm{L}>\mathrm{O}) \\
\text { Future }(\mathrm{L}>\mathrm{O})\end{array}$ & $\begin{array}{l}\text { People's money }(\mathrm{O}>\mathrm{L}) \\
\text { Tax cuts } \\
\text { Need Solution } \\
\text { Fair tax }\end{array}$ & $\begin{array}{l}\text { Meaningful tax cut } \\
\text { Process }(\mathrm{L}>\mathrm{O}) \\
\text { Victims }(\mathrm{L}>\mathrm{O})\end{array}$ \\
\hline $\begin{array}{l}\text { Security (bipartisan } \\
\text { supermajority) }\end{array}$ & Federalize & $\begin{array}{l}\text { Blame } \\
\text { Problem } \\
\text { Process } \\
\text { Privatize } \\
\text { Future }\end{array}$ & \\
\hline $\begin{array}{l}\text { Farm (bipartisan } \\
\text { supermajority) }\end{array}$ & & $\begin{array}{l}\text { Future } \\
\text { Problem } \\
\text { Solution } \\
\text { Blame } \\
\text { Size } \\
\text { Process }\end{array}$ & \\
\hline \multicolumn{4}{|c|}{$\begin{array}{l}\text { Notes: The frames in common use are included in the center column. Frames in which one side (pro- } \\
\text { con) dominates are included in the outside columns. In each case, these determinations are based on } \\
\text { difference of means tests with probabilities of } \leq .05 \text { ). Bivariate regressions examine for the effects } \\
\text { of institutional position (lobbyist }[\mathrm{L}] \text { or officeholder }[\mathrm{O}] \text { ) on each message frame taken one at a time. } \\
\text { Only coefficients with a p of } \leq .05 \text { are noted above. The direction of effects is included paren- } \\
\text { thetically. }\end{array}$} \\
\hline
\end{tabular}

argue against Bush: "We now know that children learn better in smaller classes, [and] the Bush tax cut is crowding that out" (March 14, 2001). Republican Joel Hefley (CO-5) counters with the 'flexibility' frame. "[C]hildren should not be trapped in a failing school. ... That is why H.R. 1 includes a school choice program that enables parents to send their children to another school, public or private, after 3 years of chronic failure" (May 1, 2001).

Citizens who are privy to these arguments are left unclear about what to do. If the problem in our schools results from poorly trained teachers and 
overcrowded schools, then citizens should support Mr. Miller's recommendations. If, on the other hand, the problem is lack of competition and opportunities for choice, then citizens should take Mr. Hefley's counsel.

The debate over developing a comprehensive energy policy continued into the 109th Congress. During the study period, the adversaries shared three themes in common: images about our 'future,' the merits of 'conservation' and a need to diminish our 'dependency' on foreign sources of oil. The two sides worry about different problems, however. Democrats and their allies emphasize energy shortages and the destructive effects of drilling by big oil companies ('big oil'). For solutions, they recommend more fuel 'efficiency.' Republicans and their allies emphasize market-oriented solutions ('economy') and the need for 'expansion.' Two excerpts follow to illustrate the parties' favorite frames 'big oil' (Democrat) and the 'economy' (Republican).

DeLauro (CT-3) (big oil): "I call on the President to say "no" to his big oil and big energy friends. Say "yes" to America's families that need help with rising gas and energy prices" (April 24, 2001).

Gibbons (NV-2) (economy): "H.R. 4 provides for increased domestic oil production, which will increase new jobs and boost economic development. Our economy is growing stronger by the day, but without a new energy plan there is no guarantee that we will have the resources we need to see continued improvement" (July 19, 2002).

In this debate, as in the outreach over education, the Democrats make repeated use of the 'problem' frame.

On the issue of tax cuts, opponents of lowering tax rates urge that budgetary surpluses be spent on 'other priorities,' such as balancing the budget or improving health care. The bill's supporters rarely mentioned these matters and, instead, focused on the unfairness of the inheritance tax and the so-called marriage penalty. These messages emphasize 'the people's money' and the need for a 'meaningful' tax relief.

Bartlett (MD-6) (people's money): "The surplus was created by the tax dollars of the American people. It belongs to them. There is no excuse for Congress not to give the hard-working Americans what they want, what they need and what they deserve, a tax break. It is time to give the extra money back" (March 7, 2001).

Gibbons (NV-2) (meaningful): "Mr. Speaker, spring is just around the corner, marking the beginning of the baseball season and, unfortunately, the tax season as well. Let us hit a home run for Americans. Let us pass meaningful tax relief and help them pay the mortgage, buy a computer, or simply go to school" (March 15, 2001). 
Bartlett and Gibbons, both Republicans, support the President's tax package with different yet resonant message frames.

The public discourse over airport security drew out common themes of September 11 and the need to keep our skies safe for the traveling public. The biggest controversy in this battle turned on whether to 'privatize' or 'federalize' airport screening. The Senate, which originated this bill, provided for government screeners. The President concurred, and many House Republicans, while desirous of helping Bush secure a quick victory, objected to the Senate's approach. So when addressing the nation in one-minutes, House Republicans emphasized their preference for a private, marketoriented security system. The two messages below refer to the fact that other countries 'privatize' airport security. The first is offered on the House floor by Mike Pence (IN-6). The second is presented in a press release by Americans for Tax Reform (ATR).

It (federalization) has been tried in Europe. It was rejected and failed. What we need is to strengthen our private security system, create accountability, and provide resources (Pence, January 17, 2001).

Closer examination reveals that there are a whole host of countries that have tried and rejected the Senate approach of federalizing baggage screeners. Terrorist events in the 1970s and 1980s forced governments in Europe and Israel to re-evaluate aviation security, with the eventual outcome of implementing private-sector security improvements (ATR, January 13, 2001).

The excerpts illustrate how elites from different institutions and perspectives use common language to oppose the bill's passage.

The evidence thus far supports several expectations about legislators, lobbyists and their political environments. First, the three policies with the most heterogeneous debates are the policies first promoted by President Bush in his 2000 campaign. The adversaries in these debates succeed in selecting two or three frames each that only one side dominates. Over education, it was the Democrats and their allies repeating the mantra: 'funding,' 'problem' and 'class size.' For Republicans and their allies, the language of choice was 'flexibility' and 'future.' The two policies not appearing on the President's initial agenda, and after the attacks on 9/11, are the debates with the most homogeneous speech (agriculture and airport security). Here, the adversaries argue over passage and use common themes to do it.

It is noteworthy that when message-makers anchor their arguments around common themes, as in agriculture and airport security, majorities on passage are sizable and bipartisan. When message-makers focus on different problems and solutions, talking past one another as in tax reform and energy, floor majorities are narrow and partisan. Rhetoric over education was highpitched and partisan; the vote was not. 


\section{The Participants: Allies and Adversaries}

Table 2 includes parenthetical notation to signal discordant framing when it occurs between officeholders and lobbyists on the same side of the debate. When bivariate regressions turn up nothing of significance between frame use and institution of origin, no notation appears. Take the debate over energy. Here the allies opposing the policy rely similarly on frames about the destructive effects of drilling in the Arctic National Wildlife Refuge (ANWR); the homogeneous speech elicits no notation. The allies diverge as well. Officeholders $(\mathrm{O})$ evoke more images about the 'problem' with our energy policy, while lobbyists (L) make more mention of the need for 'efficiency.' In the debate over tax policy, supportive officeholders and lobbyists make similar use of the 'meaningful' tax frame, while lobbyists more than House members raise concerns over the 'victims' of the status quo; these documents make frequent reference to two taxes that would be withdrawn under H.R. 1836, the marriage penalty and the death tax.

That both sets of allies, promoters and blockers alike, show similar levels of disunity leaves unsettled my earlier speculation about the power asymmetry of the contending sides. Perhaps both sides work for unity and miss the mark. Or perhaps it is true that only promoters try for a simple set of coherent messages but fail. The fact is, neither side achieves the consistent repetition that advances effective coalition building. Allies and adversaries do come together in coherent conversation on two policies, suggesting that the context may be at work. These are the issues least connected to presidential politics.

\section{Who Participates: The Legislators?}

The evidence on House members' involvement in these debates allows us to test three propositions from earlier work. Maltzman and Sigelman (1996) would have us believe that minority partisans use unconstrained floor time to promote policy, because they are disadvantaged in mainstream media outlets. Fenno's (2000) argument about the importance of past experiences (sequencing), suggests that Republicans will favor one minutes because of their historical success with the venue. And Morris (2001) and Maltzman and Sigelman (1996) hold that the parties' message groups draw primarily from the ideological wings of their respective caucuses.

First, in four of the five debates more Republicans than Democrats take the floor. The one instance when Democrats out-perform Republicans is airport security. Members of the Democrats' Message Group give 28 speeches to the Republican Theme Teams' $22 .^{10}$ From this preliminary examination, then, the behavior is more consistent with notions of sequencing, developed 
by Fenno (2000), than it is with minority party status as developed by (Maltzman and Sigelman 1996).

Next, more Republican speeches (77.5) than Democratic speeches (48.6) are delivered by members of the parties' message groups. The result is consistent with the Democrats' comparatively decentralized approach to policy promotion. The Democrats, for example, have no Thursday Group counterpart to the Republicans (DeGregorio 2001) and no Message Group newsletter on par with the Republicans Theme Teamer (Lipinski 2004).

Last, possibly owing to the polarized complexion of this and recent House chambers, the debaters represent ideological extremes. But they arguably mirror quite well the dominant views of their respective parties. To facilitate interpretation, I compare medians (means) using scores provided by the Americans for Democratic Action (ADA). ${ }^{11}$ The Republicans are somewhat more homogeneous than Democrats. The Republicans' median ADA score is five no matter which group you examine - the full caucus, the members of the Theme Team or the participants of these debates, regardless of team membership. Democrats are more variable but not to a significant degree. Their Message Group members are the most liberal, with a median score of 95 . Their debaters are the least liberal, with a score of 85 . And their caucus splits the difference, with a score of 90 .

The most ideologically polarized debate is that over energy policy, where the Republicans have a mean ADA score of six to the Democrats' score of 91 . The least polarized debate is over agricultural policy, but with only one Democrat participating, this is a highly tenuous result. Using the mean ADA rating as a measure of ideological positioning, the Republicans are in the single digits on four out of five policies: four (tax), five (farm) and six (education and energy). The debate over airport security taps a slightly more moderate group of Republicans with an ADA average of 14. The mean Democratic rating varies as well from highs of 91 (energy), 86 (airport security) and 84 (tax reform), to a mid-range of 69 (education) and a low of 20 (James Traficant on agriculture).

Within each party, there are a few regular participants. Republicans Gibbons (NV-2) and Pitts (PA-16) offer one-minute speeches on every issue. Several other Republicans participate nearly across-the-board, as well: Pence (IN-6), Ferguson (NJ-7), Stearns (FL-6), Ballenger (NC-10), Ryun (KS-2), and Bartlett (MD-6), to name a few. From the Democrats' ranks, DeLauro (CT-3), DeFazio (OR-4), and Inslee (WA-1) frequently address the House. Traficant $(\mathrm{OH}-17)$ is a colorful regular, but his rhetoric is seldom on topic. With an ADA median of 20, Traficant is also ideologically right of the average Message Group member and caucus. While atypical, he is not alone. His score fits well with Democrats from Georgia, Kentucky and Texas, to name a few. 


\section{Who Participates: The Lobbyists?}

Table 3 lists the lobby-groups that most actively participate in issuing press releases. Each cell reports the total number of documents the listed groups authored for their position (for or against) as a portion of all press releases for the specified policy. The balance of messages, unaccounted for by the listed participants, comes from groups that limit their activity to one or two messages each. It is noticeable that a handful of organizations, and sometimes as few as two, account for two-thirds or more of the press release activity on a given side and issue.

In two cases, occupational groups dominate both sides of the debate. In the fight over education reform, the National Education Association (NEA) and the American Federation of Teachers (AFT) produce 76 percent of all the messages against No Child Left Behind. In the fight over airport security, Securicor supplies two of only three releases to block federalizing airport security personnel. Securicor and Securitas AB, which owns the second largest U.S. airport screening company, Global Aviation, supported uniform standards and funds for training. On balance, they took strong exception to being replaced by a government-run service. The supporters of education reform and airport security are predominately occupational as well. The Business Coalition for Excellence in Education (BCEE) and CATO, a libertarian think tank, together issued 76 percent of the press releases in support of the President's education initiative. And 77 percent of all press releases promoting airport security came from three occupational groups: the American Federation of Government Employees (AFGE), the Airline Pilots Association (ALPA), and the Air Transport Association (ATA).

Occupational and citizen groups are fairly evenly matched over energy reform and agricultural security. Pro-environment, citizen groups fought drilling for oil in ANWR. Four groups supply 86 percent of all the press releases against H.R. 4. They include: the Sierra Club (SC), the Alaskan Wilderness League (AWL), the Wilderness Society (WS), and the Natural Resources Defense Council (NRDC). ${ }^{12}$ The criticisms of these groups were countered by numerous press releases in support of a comprehensive energy plan. Table 3 lists four groups but this is deceptive. The Teamsters and the National Mining Association (NMA) produced press releases on their own. Over a thousand additional business, trade, and consumer organizations joined forces in two broad-based alliances to push back against the claims of the environmental groups. The Alliance to Save the Energy (ASE) and Alliance for Energy and Economic Growth (AEEG) continue their respective outreach to build consensus around a comprehensive energy policy. ${ }^{13}$ Together these groups produced 66 percent of the press releases in support of the proposed energy overhaul. 
Table 3. Breakdown of Messages by Policy,
Institution of Origin, and Stance on Passage

\begin{tabular}{|c|c|c|c|c|}
\hline \multirow[b]{2}{*}{ Policies } & \multicolumn{2}{|c|}{ Allies in Opposition } & \multicolumn{2}{|c|}{ Allies in Support } \\
\hline & Lobbyists & Legislators & Lobbyists & Legislators \\
\hline \multirow[t]{3}{*}{ Education } & $N E A$ & Miller* & $B E E$ & Gibbons* \\
\hline & $A F T$ & & CATO & $\begin{array}{l}\text { Ferguson } \\
\text { Ballenger* }\end{array}$ \\
\hline & $46 / 60(77)$ & $2 / 11(18)$ & $14 / 18(77)$ & $7 / 14(50)$ \\
\hline \multirow[t]{6}{*}{ Energy } & Sierra Club & Filner* & Teamsters & Gibbons* \\
\hline & AWL & Inslee* & ASE (Alliance) & Wilson \\
\hline & WS & DeLauro* & AEEG (Alliance) & Stearns* \\
\hline & NRDC & Baldacci* & CEI & Pitts* \\
\hline & & & $N M A$ & $\begin{array}{l}\text { Rehberg } \\
\text { Biggert* }\end{array}$ \\
\hline & $97 / 117(83)$ & $12 / 26(46)$ & $83 / 125(66)$ & $32 / 72(44)$ \\
\hline \multirow[t]{5}{*}{ Farm } & $\mathrm{AKC}$ & Smith* & $A F B$ & Trafficant* \\
\hline & TFCS & & $N A W G$ & \\
\hline & $\mathrm{SC}$ & & CFRA & \\
\hline & & & DU & \\
\hline & $18 / 22(82)$ & $4 / 7(57)$ & $47 / 61(77)$ & $1 / 1(100)$ \\
\hline \multirow[t]{6}{*}{$\operatorname{Tax}$} & $A F L$ & Sandlin* & $N F I B$ & Gibbons* \\
\hline & UCC & DeLauro* & FRC & Pitts* \\
\hline & $\mathrm{AF}$ & DeFazio* & AFTR & Stearns* \\
\hline & & & CSE & Ryun* \\
\hline & & & $\mathrm{AFB}$ & Bartlett* \\
\hline & $18 / 22(82)$ & 9/44 (24) & $44 / 51(86)$ & $33 / 49(67)$ \\
\hline \multirow[t]{6}{*}{ Security } & Securicor & Foley* & $A F G E$ & DeFazio* \\
\hline & $N F I B$ & Pence* & $A L P A$ & Rodriquez* \\
\hline & & Hefley* & $A T A$ & Crowley* \\
\hline & & & & Inslee* \\
\hline & & & & Strickland \\
\hline & $3 / 3(100)$ & $10 / 22(45)$ & $13 / 17(77)$ & $14 / 28(50)$ \\
\hline \multicolumn{5}{|c|}{$\begin{array}{l}\text { Notes: The groups in italics are occupational organizations. Non-occupational groups include citizer } \\
\text { groups and think tanks. See the text for full names. The starred officeholders are members of thei } \\
\text { parties' respective communications' teams. The within-cell tallies show the degree to which th } \\
\text { listed participants dominate in message making (see percents of total in parentheses). }\end{array}$} \\
\hline
\end{tabular}


Tax relief drew out a mix of groups, but this time the citizen groups numerically dominate message production. We see Americans for Tax Reform (AFTR), Citizens for a Sound Economy (CSE), and the Family Research Council (FRC) - anti-tax and pro-family organizations - assisted by one think tank (Heritage Foundation) and two occupational groups - the National Federation of Independent Business (NFIB) and the Farm Bureau (FB). The Farm Bureau focused almost exclusively on ending the 'death' tax. ${ }^{14}$ The AFL and two citizen groups worked to weaken and defeat the tax cuts. The citizen groups include the United Church of Christ (UCC) and the Institute for America's Future (AF).

In keeping with policy-centered studies of interest-group advocacy, no one group-type dominates. Occupational-group messages lead outreach on the education and airport security bills, where jobs were clearly at stake. Occupational and citizen-group messages split the field in debates over energy and agriculture. And while both group-types participate in tax reform, citizen groups numerically dominate the message-making.

Scholars tell us that citizens act out of fear more than hope (Baumgartner and Leech 1998; Riker 1996), so it is reasonable to expect more references to themes of danger and deprivation than themes of reward and optimism. The contents of the press releases support this claim. The lobbyists frequently stir audiences with concerns over lost jobs, a degraded environment, tyranny of an over-zealous government, and threats to the nation's security. We see the teachers unions and Securicor earlier alleging harm to the livelihoods of teachers and baggage screeners, respectively. The American Kennel Club, successfully blocked a provision of the farm bill, by using this mantra about the evils of big government depriving dog breeders of cherished discretion: " $[\mathrm{I}] \mathrm{t}$ is 'intrusive and excessive' government regulation of dog owners' breeding decisions (January 24, 2002)." ${ }^{\prime 15}$ And the environmental groups emphasize the dangers of H.R. 4.

Sierra Club (big oil): "To drill our way out of energy problems creates more global warming, more air pollution and devastates our last wildlands" (February 26,2001$)$.

Alaskan Wilderness League (big oil): "Ninety-five percent of Alaska's vast coastline is already open for drilling. Protecting a small fraction of this icy paradise doesn't seem unreasonable. Bush and his Republican allies would do well to reconsider their hell-bent dominion over the land and seek ways to live in better harmony with the natural world" (February 21, 2001).

Even the defenders of the energy plan justify passage, in part, on the grounds that the status quo makes us vulnerable to hostile oil-producing nations, the 'dependency' frame. 
Two final observations: Interest organizations cleverly intermingle their groups' policy goals with what they deem is best for America's future (the 'future' frame). ${ }^{16}$ And the 'process' frame, more than the rest, tends toward factual neutrality. The lobby groups simply report on recent and upcoming events: hearings, votes, deliberation and the like.

\section{Conclusion}

Our understanding of political behavior deepens as evidence mounts from new and varied methodological approaches. This study provides a firstever look at the rhetorical arguments expressed by House members and lobbyists as they endeavor to shape policy. The results affirm and enrich important themes in political science. Several findings have normative as well as positive implications for our assessment of American governance. And the five-case comparison, while inadequate for drawing general conclusions, provides valuable insights for further investigation.

While it often occurs that lobbyists and legislators work well together, adopting the same frames in support of their mutual interests, there are times when different institutional positions and goals seemingly prompt them to stress different language. Befitting their power of the purse, lawmakers adopt the phrase the 'people's money.' Anti-tax groups might philosophically applaud the sentiment but they do not employ that frame to the same extent. Similarly, lobbyists announce upcoming 'process' opportunities for citizen engagement more than do officeholders, befitting the mobilizing function of interest groups. That elites take seriously the interests of their principals bodes well for responsive governance. Lobbyists' press releases also outnumber legislators' one-minute floor speeches, sometimes by sizable numbers. This result conforms to scholarly accounts of the symbiotic relationship between lawmakers and lobbyists. Indeed, for all the promotion that lobbyists offer over and above the lawmakers, they extend the influence of the individuals with whom they partner.

Looking within the House at the parties' mechanisms for coordinating policy speech, the evidence affirms prior accounts that Democrats run a more decentralized operation than Republicans. Whereas most Democratic speakers are not formal members of the leaderships' message arm, most Republicans are. That said both parties make effective use of coordinating floor time. With the exception of the debate over energy policy when Republicans dominated, the parties field a comparable number of speakers. Their champions come from the ideological wings of their caucuses. And their rhetoric diverges along predictable party lines.

In keeping with policy-centered studies of interest-group advocacy, no one group-type dominates. The promotional playing field is open and com- 
petitive. Occupational-group messages lead outreach on the education and airport security bills, where jobs were clearly at stake. Occupational and citizen-group messages split the field in debates over energy and agriculture. And while both group-types participate in tax reform, citizen groups numerically dominate the message-making. Also, in keeping with the known burdens of wielding positive power, the supporters of bill passage produce more rhetoric than do opponents. If providing a homogenous front is more important for one side than the other, the evidence shows no such asymmetry. Rhetorical differences occur among allies regardless of their position on passage.

In two of five cases the participants debate contentious issues with shared themes. This occurs in the speech over agriculture and aviation-one broad and one narrow-gauged issue - both somewhat removed from the acrimony of presidential politics. Citizens who follow these arguments hear adversaries engage in a sensible back and forth. Such is not the case in the outreach over education, energy and taxation. The adversaries in these debates share a few themes but, in the main, the debates are polarized and emotion-laden. Citizens observing these conversations watch two opposing sides talk past each other. Audiences are left to fill in the blanks and reconcile the differences on their own.

Also, negative images are popular regardless of ones' stance. We see references to (1) impending harm should the new policy pass (obliteration of the Alaskan paradise [H.R. 4], lost opportunities to fix other national priorities [H.R. 1836], and the ruin of public schools [H.R. 1]) and (2) unnecessary harm should the new policy fail to pass (destruction of the family farm [H.R. 2646] and the demise of the American dream [H.R. 1836]).

Finally, we can speculate from the patterns thus far that political speechmaking varies with the issues and their contexts. I offer three competing scenarios, all worthy of further study. First, it is the timing of the proposal that matters; early deliberations will be colored by the spill-over effect of a combative presidential election. Second, it is partisan shifts in power that matter; one side will talk past another side as a consequence of party switching in the White House. And third, timing and party switching aside, it is the content of the policy change that is in play; agricultural policy, for example, is always homogenous because of the constituency nature of this issue. 


\section{APPENDIX. Excerpts from One-Minute Speeches and Interest Group Press Releases, Frame Names in Brackets}

Ms. DeLauro (Dem) The President's tax plan would weaken our economy, and it fails to Provide fair and significant tax cuts for those who need it the most. ['fairness' and 'tax cuts'].

Mr. Frost (Dem) Democrats are committed to an honest, fair and fiscally responsible Budget that includes all of America's priorities, from education and defense to health ['priorities']

Ms. Joanne Davis (Rep) President Bush recognizes that after the bills are paid, the leftover funds belong to the American taxpayers. Rejecting a plan to use a portion of the surplus for tax relief is the equivalent of paying for a gallon of milk at the grocery store with a $\$ 10$ bill and having the cashier refuse to give you back the change. It is wrong. ['people's money']

Americans for Tax Reform. Closer examination reveals that there are a whole host of countries that have tried and rejected the Senate approach of federalizing baggage screeners. Terrorist events in the 1970s and 1980s forced governments in Europe and Israel to re-evaluate aviation security, with the eventual outcome of implementing private-sector security improvements ['privatize'].

U.S. Chamber of Commerce. This legislation will ensure a reliable, affordable domestic supply to meet our future needs and protect our national security. It expands the use of nuclear power and renewable energy sources, including hydro, biomass, solar, and wind. ['future'].

Alaskan Wilderness League. Ninety-five percent of Alaska's vast coastline is already open for drilling. Protecting a small fraction of this icy paradise doesn't seem unreasonable. Bush and his Republican allies would do well to reconsider their hell-bent dominion over the land and seek ways to live in better harmony with the natural world. ['big oil'].

\section{NOTES}

${ }^{1}$ Depending on the discipline, scholars use a variety of terms: schema, frames, heresthetics, sense-units, and themes. I use these words interchangeably to connote the common-sense meaning of an argument. For a discussion of framing effects see Druckman (2001).

${ }^{2}$ John Kingdon's (1973) early work on legislators' voting decisions, taught us that high party unity is more like the effect of members' consulting trusted colleagues and not evidence of strong party leaders.

${ }^{3}$ Both parties hire speechwriters, pollsters and consultants, but only the Republicans have formalized the process to include a monthly newsletter, entitled the Theme Teamer (Morris 2001).

${ }^{4}$ In Outside Lobbying, Kenneth Kollman finds, for example, that unions employ protest and other highly visible tactics that groups with voluntary memberships more often eschew (1998). 


\section{2 | Christine DeGregorio}

${ }^{5}$ While they do not address message politics per se, Ainsworth (2000) and Krehbiel (1999) provide theoretical proof of the delicacies of coalition building when managing interest groups and legislatures respectively.

${ }^{6}$ Conservative allies to House Republicans in the years prior to 1995 concur with this depiction. They discuss their lack of message coordination like this. "We were on the outside looking in." It was enough to "throw sand in the gears" (DeGregorio 2001, 279).

${ }^{7}$ For a complete list of the organizations, see DeGregorio (2009).

${ }^{8}$ The content analysis of every speech and press release is done with a software program, entitled NUD*IST5, which is available through QSR International in Melbourne, Australia.

${ }^{9}$ To be sure, the Web offers lobby groups boundless opportunity for posting messages, more, certainly, than lawmakers may reap through the one-minute venue. Nonetheless, the lawmakers limited their speech to a few days of concentrated effort per bill. And in the case of agricultural policy, deliberation passed with almost no one addressing the floor through the one-minute speeches.

${ }^{10}$ Albeit Republicans turn out more than Democrats on farm security, neither party has much of a showing. Smith (MI-7) gives four of seven speeches for the Republican leadership's position to oppose the high costs of H.R. 2646. Traficant (OH-17) makes the only speech for the Democrat position, which favors farm supports.

${ }^{11}$ The means and medians are quite similar, showing no remarkable skew. Also, the tests of significance on means and relative distances on medians are comparable, whether I use the first dimension of the dw-nominate score, provided by Poole and Rosenthal (1997) or the ADA score. For data and a discussion of adjusted ADA scores see Anderson and Habel (2008).

${ }^{12}$ The Natural Resources Defense Council identifies itself as "a national, nonprofit organization of scientists, lawyers and environmental specialists dedicated to protecting public health and the environment." I categorize the group as a citizen group because of their shared concern over public health and the environment. The group issued many reports showing how "America can meet its energy needs without drilling in Alaska Wildlife Refuge" (February 6, 2001).

${ }^{13}$ Both alliances are large and diverse. The Alliance for Energy and Economic Growth is a broad coalition of business, community and labor organizations. Safe Energy Alliance includes corporations, trade association, public interest groups, and research organizations.

${ }^{14}$ This is a typical refrain from the Farm Bureau. "Farms and ranches are the backbone of rural America, and the loss of these family businesses to pay the death tax hurts the families of deceased producers, the rural communities that depend on farming and the general health of American agriculture" (April 4, 2001).

${ }^{15}$ The American Kennel Club (AKC) waged a successful fight against the Puppy Protection Act. A typical press release reads: "The AKC remains opposed to the PPA amendment to the Farm Bill because it broadens the scope of the Animal Welfare Act to govern the breeding of dogs and socialization requirements" (February 7, 2002).

${ }^{16}$ This is the 'future' frame as applied by the Farm Bureau. "Bush's final tax relief bill kills the death tax, retains stepped-up bases and provides additional tax relief to bolster the future of America's farm and ranch families" (May 24, 2001). 


\section{REFERENCES}

Abramowitz, Alan A. 2001. "Mr. Mayhew, Meet Mr. Delay," or the Electoral Connection in the Post-Reform Congress. PS: Political Science and Politics 34(2):257-258.

Ainsworth, Scott. 2000. Analyzing Interest Groups. New York: W.W. Norton and Co.

Aldrich, John, and David Rohde. 1997. The Transition to Republican Rule in the House: Implications for Theories of Congressional Politics. Political Science Quarterly 112(4):541-567.

Anderson, Sarah, and Philip Habel, 2008, Revisiting Adjusted ADA Scores for the U.S. Congress, 1947-2007. Political Analysis. Advance Access published on December $16,2008$.

Baumgartner, Frank R. 2007. EU Lobbying: A View from the U.S. Journal of European Public Policy 14(3):482-488.

Baumgartner, Frank R., and Beth L. Leech. 1998. Basic Interests: The Importance of Groups in Politics and in Political Science. Princeton, NJ: Princeton University Press.

Berry, Jeffrey. 1999. The New Liberalism. Washington, DC: Brookings Institution.

Chin, Michelle L., Jon Bond, and Nehemia Geva. 2000. A Foot in the Door: An Experimental Study of PAC and Constituency Effects on Access. Journal of Politics 62(2):534-549.

Chong, D., Herber McClosky, and John Zaller. 1983. Patterns of Support for Democratic and Capitalist Values in the United States. British Journal of Political Science 13(4):401-440.

Cobb, R.W., and C.D. Elder. 1983. Participation in American Politics: The Dynamics of Agenda-Building. Boston, MA: Allyn \& Bacon.

Connelly, William, and John J. Pitney. 1994. Congress's Permanent Minority: Republicans in the U.S. House of Representatives. Lanham, MD: Rowman and Littlefield Publishing Group.

Cook, Timothy. 1998. Governing With the News: the News Media as a Political Institution. Chicago: The University of Chicago Press.

Christine DeGregorio, 2009, Calling Out the Troops: Interest Groups, Press Releases and Policy Promotion Through Speech. Politics and Policy 37:463-484.

DeGregorio, Christine. 2001. Party Leadership in the U.S. House of Representatives: Making Sense out of Ambition and Context. Congress and the Presidency 28(1): 19-45.

DeGregorio, Christine. 1997. Networks of Champions: Leadership, Access and Advocacy in the U.S. House of Representatives. Ann Arbor: The University of Michigan Press.

Downs, Anthony. 1957. An Economic Theory of Political Action in a Democracy. Journal of Political Economy 65(2):135-150.

Druckman, James. 2001. On the Limits of Framing Effects: Who Can Frame? Journal of Politics 63(4):1041-1066.

Dwyre, Diane, and Victoria Farrar-Myers. 2000. The Legislative Labyrinth. Washington, DC: Congressional Quarterly Books.

Egan, Patrick J. 2008. Issue Ownership and Representation: A Theory of Legislative Responsiveness to Constituency Opinion (August 19, 2008). Available at SSRN: http://ssrn.com/abstract=1239464. 


\section{4 | Christine DeGregorio}

Evans, Charles Lawrence. 2001. Committees, Leaders, and Message Politics. In Congress Reconsidered, 7th ed., eds. Lawrence C. Dodd and Bruce I. Oppenheimer. Washington, DC: CQ Press.

Evans, Diana. 2004. Greasing the Wheels: Using Pork Barrel Projects to Build Majority Coalitions in Congress. New York: University of Cambridge Press.

Fenno, Richard F. 2000. Congress at the Grassroots: Representational Change in the South, 1970-1998. Chapel Hill: University of North Carolina Press.

Gingrich, Newt. 1997. Lessons Learned the Hard Way. New York: Harper Collins Publishers.

Goffman, E. 1974. Frame Analysis. New York: Harper Row.

Hall, Richard L., and Alan V. Deardorff. 2006. Lobbying as Legislative Subsidy. American Political Science Review 100(1):69-84.

Hansen, John M. 1985. The Political Economy of Group Membership. American Political Science Review 79(1):79-96.

Harris, Douglas B. 2005. Orchestrating Party Talk: A Party-Based View of One-Minute Speeches in the House of Representatives. Legislative Studies Quarterly 30(1):127141.

Harris, Douglas B. 1998. The Rise of the Public Speakership. Political Science Quarterly 113(2):193-212.

Hofstetter, C.R., D. Barker, J.T. Smith, G.M. Zari, and T.A Ingrassia. 1999. Information, Misinformation, and Political Talk Radio. Political Research Quarterly 52:333369.

Hurley, Patricia A. 2001. David Mayhew's “Congress: The Electoral Connection" after 25 Years. Political Science and Politics 34(2):259-261.

Iyengar, Shanto. 1994. Is Anyone Responsible?: How Television Frames Political Issues. Chicago: University of Chicago Press.

Iyengar, Shanto. 1990. Framing Responsibility for Political Issues. Political Behavior 12(1):19-40.

Jerit, Jennifer. 2008. Issue Framing and Engagement: Rhetorical Strategy in Public Policy Debates. Political Behavior 30(1):1-24.

Kahn, Gabriel. 1995. Bonior Overhauls His Whip Operation. Roll Call, January 16.

Kahneman, Daniel and Amos Tversky. 1979. Prospect Theory: An Analysis of Decision under Risk. Econometrica 47(2):263-292.

Kingdon, John. [1973] (1981 and 1989). Congressmen's Voting Decisions, 3rd ed. New York: Harper and Row.

Kollman, K. 1998. Outside Lobbying. Princeton, NJ: Princeton University Press.

Krebbs, Ronald R., and Patrick T. Jackson. 2007. Twisting Tongues and Twisting Arms: The Power of Political Rhetoric. European Journal of International Relations 13(1):35-66.

Krehbiel, Keith. 1998. Pivotal Politics. Chicago: University of Chicago Press.

Krehbiel, Keith. 1995. Cosponsors and Wafflers from A to Z. American Journal of Political Science 39(4):906-923.

Lipinski, Daniel. 2004. Congressional Communications. Ann Arbor: University of Michigan Press.

Luntz, Frank. 2006. Words That Work. New York: Hyperion Publishers.

Maltzman, Forrest, and Lee Sigelman. 1996. The Politics of Talk: Unconstrained Floor Time in the U.S. House of Representatives. Journal of Politics (58):819-830.

Mayhew, David. 1974. Congress: the Electoral Connection. New Haven, CT: Yale University Press. 
Mayhew, David. 2001. Observations on "Congress: The Electoral Connection" a Quarter Century after Writing It. Political Science and Politics 34(2):251-252.

Morris, Jonathan. 2001. Reexamining the Politics of Talk: Partisan Rhetoric in the 104th Congress. Legislative Studies Quarterly 26(1):101-121.

Niven, David. 1996. Shaping the Congressional Debate on the Gulf War. Congress and the Presidency 23(1):33-56.

Page, Benjamin I. 1996. Who Deliberates? Mass Media in Modern Democracy. Chicago: University of Chicago Press.

Riker, William. H. 1996. The Strategy of Rhetoric: Campaigning for the American Constitution. New Haven, CT: Yale University Press.

Roberts, Cokie, and Steve Roberts. 1995. The Real Conservative Revolution. The Baltimore Sun, January 17, p. 11A.

Rocca, Michael S. 2007. Nonlegislative Debate in the U.S. House of Representatives. American Politics Research 35(1):489-505.

Rosenstone, Steven.J., and John Mark Hansen. 1993. Mobilization, Participation, and Democracy in America. New York: Macmillan.

Sigelman, Lee, Christopher Deering, and Burdett A. Loomis. 2001. 'Wading Knee Deep in Words, Words, Words': Senatorial Rhetoric in the Johnson and Clinton Impeachment Trials. Congress and the Presidency 28:119-139.

Sinclair, Barbara. 2006. Party Wars: Polarization and the Politics of National Policy Making. Norman: University of Oklahoma Press.

Sinclair, Barbara. 2007. Unorthodox Lawmaking. Washington, DC: Congressional Quarterly Press.

Smith, Steven S. 2007. Party Influence in Congress. New York: Cambridge University Press.

Truman, David. 1951. The Congressional Process. New York: Alfred A. Knopf.

Zaller, John. 1992. The Nature and Origins of Mass Opinion. New York: Cambridge University Press. 